\title{
Article \\ Genetics of Germination and Seedling Traits under Drought Stress in a MAGIC Population of Maize
}

\author{
Soumeya Rida $^{1}$, Oula Maafi ${ }^{1}$, Ana López-Malvar ${ }^{2}{ }^{*} \mathbb{D}$, Pedro Revilla $^{3} \mathbb{D}$, Meriem Riache $^{1}$ \\ and Abderahmane Djemel ${ }^{1}$ (D)
}

1 Higher National Agronomic School (ENSA), L-RGB, Hassan Badi, El Harrach, Algiers 16004, Algeria; soum.rida@gmail.com (S.R.); oulamaafi@gmail.com (O.M.); m.riache93@gmail.com (M.R.); djemeldahmane@yahoo.fr (A.D.)

2 Facultad de Biología, Departamento de Biología Vegetal y Ciencias del Suelo, Agrobiología Ambiental, Calidad de Suelos y Plantas, Universidad de Vigo, As Lagoas Marcosende, 36310 Vigo, Spain

3 Misión Biológica de Galicia (CSIC), Apartado 28, E-36080 Pontevedra, Spain; previlla@mbg.csic.es

* Correspondence: alopezmalvar@uvigo.es

check for

updates

Citation: Rida, S.; Maafi, O.; López-Malvar, A.; Revilla, P.; Riache, M.; Djemel, A. Genetics of Germination and Seedling Traits under Drought Stress in a MAGIC Population of Maize. Plants 2021, 10, 1786. https://doi.org/10.3390/ plants10091786

Academic Editors: Bhakti Prinsi and Luigi Lucini

Received: 29 July 2021

Accepted: 24 August 2021

Published: 27 August 2021

Publisher's Note: MDPI stays neutral with regard to jurisdictional claims in published maps and institutional affiliations.

Copyright: (C) 2021 by the authors. Licensee MDPI, Basel, Switzerland. This article is an open access article distributed under the terms and conditions of the Creative Commons Attribution (CC BY) license (https:/ / creativecommons.org/licenses/by/ $4.0 /)$.

\begin{abstract}
Drought is one of the most detrimental abiotic stresses hampering seed germination, development, and productivity. Maize is more sensitive to drought than other cereals, especially at seedling stage. Our objective was to study genetic regulation of drought tolerance at germination and during seedling growth in maize. We evaluated 420 RIL with their parents from a multi-parent advanced generation inter-cross (MAGIC) population with PEG-induced drought at germination and seedling establishment. A genome-wide association study (GWAS) was carried out to identify genomic regions associated with drought tolerance. GWAS identified 28 and 16 SNPs significantly associated with germination and seedling traits under stress and well-watered conditions, respectively. Among the SNPs detected, two SNPs had significant associations with several traits with high positive correlations, suggesting a pleiotropic genetic control. Other SNPs were located in regions that harbored major QTLs in previous studies, and co-located with QTLs for cold tolerance previously published for this MAGIC population. The genomic regions comprised several candidate genes related to stresses and plant development. These included numerous drought-responsive genes and transcription factors implicated in germination, seedling traits, and drought tolerance. The current analyses provide information and tools for subsequent studies and breeding programs for improving drought tolerance.
\end{abstract}

Keywords: maize; drought stress; genome wide association study (GWAS); germination; seedlings; candidate genes

\section{Introduction}

Predictions of climate change leading to abiotic stresses, such as rising drought events and higher temperature, indicate an intensification in their severity and frequency [1], and an increased variability of rainfall, in the next 40 years [2]. Drought is one of the main challenges of agriculture at the global scale because it is the most serious and prevalent abiotic stress hampering the potential productivity of crops [3]. Most crops are susceptible to drought and can experience yield losses of more than 50\%. Moreover, maize is more sensitive to drought than other cereals [4]. As a result, annual economic losses due to the reduction of maize production caused by drought stress amount to 15-20\% [4-7].

The global demand for maize is increasing as a source of food, feed, and industrial material in line with the increase in the size of the human population [8]. However, future drought stress caused by accelerated global warming will be detrimental for maize production [9]. A share in excess of $20 \%$ of the maize growing area will be affected by drought, particularly in the East Asian, South American, and Western European major maize producing zone $[10,11]$. Considering the agricultural and economic importance of 
maize, and the constraints imposed by current climate change, the improvement of maize for drought tolerance is a priority in breeding programs as an important part of the solution to stabilize global maize production [12].

Because drought tolerance involves diverse physiological parameters and is controlled by a large number of genes with small effects, its improvement is difficult [13]. Therefore, identification of the genetic regulation of drought tolerance is of great importance for establishing efficient breeding programs [14]. Genetic mapping is a powerful strategy that exploits genomic information to dissect complex traits and identifies genetic determinants that may lead to crop improvement [15]. A higher resolution is possible through association mapping than with traditional QTL mapping, and association mapping is suitable for simultaneously mapping multiple traits [16]. Furthermore, maize is an ideal model plant to conduct association studies because of its great genetic diversity and genome-wide rapid linkage disequilibrium (LD) decay [17].

The genome-wide association study (GWAS) is a widely adopted technique for decoding genotype-phenotype associations in many species through advances in Next Generation Sequencing technologies [18]. In maize, GWAS has been used to locate regions of the genome associated with complex traits [19-21] and contributed to the understanding of maize functional genomics and genetics [18]. GWAS has been widely used in maize as an effective means to find candidate genes. Tian et al. [22] determined the genetic basis of important leaf architecture traits and identified some of the key genes. Revilla et al. [23] conducted GWAS in temperate maize inbred lines to identify genes related to cold tolerance. Wang et al. [24] performed GWAS and identified 42 candidate genes that contribute to $55.2 \%$ of the natural variation of drought tolerance in maize seedlings. Furthermore, several GWAS reports are available on other target genes for crop improvement [25]. The inclusion of more diverse founders is one means to further increase GWAS mapping resolution [18].

The multi-parent advanced generation inter-cross (MAGIC) population represents a new and powerful tool allowing the high-resolution mapping of quantitative traits [26,27]. Crop improvement against abiotic stresses such as drought requires large germplasm diversity screening [27], and the combination of multiple founders provides a higher genetic and phenotypic diversity within a single mapping population. Thus, the MAGIC population is a useful tool to develop strategies to cope with drought stress.

Water scarcity influences crops at different levels of their growth and development [28], and affects maize from germination to maturity [29]. In addition to yield losses, drought limits the germination rate [30] and reduces seedling establishment [31]. Although drought tolerance at different stages of development is unrelated [32], several studies and breeding programs have been based mainly on yield, flowering, and adult vegetative phases. In contrast, limited research attention has been paid to study maize at early stages of development.

Evaluation of drought tolerance at the seedling stage is necessary to predict good crop stands at maturity. In the early stages of cultivation, drought causes a significant decline in germination rates and increase in seedling mortality, and is detrimental to plant viability and development [33]. Phenotyping young seedlings under controlled conditions is a useful approach to identify candidate drought-tolerant genotypes, and can reduce the laborious and time-consuming selection under field conditions [34]. Drought stress reduces the phenotypic expression of all the seedling traits [35]. Shoot and root traits are potentially used in drought-tolerance screenings, and are inhibited by drought $[36,37]$.

Because the assessment of root behavior is not possible in the field [38], several authors have reported that the induction of water stress by Polyethylene glycol (PEG) is a reliable approach for the assessment of water stress in germplasm collections of maize [39-41]. This approach has been used for the study of water stress at early stages [41-45]. Direct studies on root traits are highly complex. Thus, as an alternative, genome-wide association studies (GWASs) have been used to identify superior alleles and determine their use in forward breeding, in the study of the available genotypic variability of such complex traits [46]. The objective of this research was to study the genetic regulation of drought tolerance at 
germination and during seedling growth in maize to identify associated genomic regions and candidate genes.

\section{Results}

\subsection{Phenotypic Variation and Establishment}

Drought stress had detrimental effects and the mean values of each trait were significantly reduced under water stress compared to control conditions (Table 1). The reduction caused by drought varied from $90 \%$ in coleoptile length and dry weight to $40 \%$ for germination. A large phenotypic variation for all traits was found under control conditions and under induced drought (Table 1). The ranges of variation were reduced under drought compared to control conditions, except for germination, and the minimum was zero for all traits under drought stress. The data obtained showed that the distribution of the traits was approximately symmetric for germination and root length under both conditions. The phenotypic values of all other traits were positively skewed in both conditions, except for germination (Table 1).

Table 1. Mean \pm standard error (s.e.), coefficient of variation (CV), skewness and kurtosis, minimum and maximum of germination and establishment-related traits evaluated under water stress obtained with $200 \mathrm{~g} \mathrm{~L}^{-1}$ of Polyethylene glycol 6000 and control.

\begin{tabular}{l|l|l|l|l|l|l|l}
\hline Variable & Mean \pm s.e. & CV & \multicolumn{1}{l}{ Skewness } & Kurtosis & Min. & Max. \\
\hline Control $\left(0 \mathrm{~g} \mathrm{~L}^{-1}\right.$ of Polyethylene glycol 6000) & $74.44 \pm 9.45$ & 21.98 & $-0.77^{* *}$ & 0.38 & 20.0 & 100 \\
\hline Germination & $21.34 \pm 5.08$ & 41.22 & $0.63^{* *}$ & 0.05 & 6.2 & 51.8 \\
\hline Coleoptile length & $39.38 \pm 8.75$ & 38.46 & $0.50^{* *}$ & -0.05 & 7.5 & 94.1 \\
\hline Root length & $0.58 \pm 0.14$ & 41.43 & $2.99^{* *}$ & $16.85^{* *}$ & 0.2 & 2.5 \\
\hline Coleoptile length/ Root length ratio & $51.39 \pm 16.18$ & 54.53 & $1.07^{* *}$ & $1.29^{* *}$ & 6.7 & 160 \\
\hline Coleoptile dry weight & $32.40 \pm 11.64$ & 62.15 & $1.77^{* *}$ & $4.98^{* *}$ & 3.3 & 136.7 \\
\hline Root dry weight & $1.81 \pm 0.44$ & 42.16 & $1.54^{* *}$ & $3.06^{* *}$ & 0.7 & 5.2 \\
\hline Coleoptile dry weight/Root dry weight ratio & & & & \\
\hline Water stress (200 g L ${ }^{-1}$ of Polyethylene glycol 6000) & $42.95 \pm 12.183$ & 49.14 & -0.02 & $-0.66^{*}$ & 0 \\
\hline Germination & $2.14 \pm 1.343$ & 108.73 & $1.34^{* *}$ & $1.76^{* *}$ & 0 \\
\hline Coleoptile length & $15.95 \pm 3.237$ & 35.16 & $0.53^{* *}$ & $0.97^{* *}$ & 0 \\
\hline Root length & $0.13 \pm 0.084$ & 115.69 & $1.74^{* *}$ & $4.70^{* *}$ & 0 \\
\hline Coleoptile length/Root length ratio & $5.42 \pm 4.858$ & 155.34 & $2.76^{* *}$ & $12.14^{* *}$ & 0 \\
\hline Coleoptile dry weight & $10.68 \pm 4.644$ & 75.29 & $1.16^{* *}$ & $1.99^{* *}$ & 0 \\
\hline Root dry weight & $0.46 \pm 0.320$ & 119.96 & $1.86^{* *}$ & $4.34^{* *}$ & 0 \\
\hline Coleoptile dry weight/Root dry weight ratio & 66.7 \\
\hline
\end{tabular}

$*, * * * * *$ significant at $0.05,0.01$ and 0.001 probability level, respectively.

\subsection{Phenotypic Correlations between Measured Traits}

Phenotypic correlations between the genotypes under each treatment showed different responses to drought stress (Table 2). Under well-watered conditions, significant $(p<0.01)$ correlations were observed between germination $(\mathrm{G} \%)$ and establishment related-traits. All correlations were positive except those between germination and the ratios coleoptile length/root length (CL/RL) and coleoptile dry weight/root dry weight (CDW/RDW). Coleoptile length (CL) was strongly correlated with root length $(R L)(r=0.75)$ and coleoptile dry weight $(\mathrm{CDW})(\mathrm{r}=0.83)$. In addition, root length $(\mathrm{RL})$ was highly correlated with coleoptile dry weight $(\mathrm{CDW})(\mathrm{r}=0.70)$ and root dry weight $(\mathrm{RDW})(\mathrm{r}=0.74)$, and the ratio coleoptile dry weight/root dry weight $(\mathrm{CDW} / \mathrm{RDW})$ was positively correlated with the ratio coleoptile length/root length $(\mathrm{CL} / \mathrm{RL})(\mathrm{r}=0.68)$. 
Table 2. Phenotypic correlation coefficients among germination and establishment related-traits measured in the MAGIC population evaluated under water stress (below diagonal) obtained with $200 \mathrm{~g} \mathrm{~L}^{-1}$ of Polyethylene glycol 6000 and under well-water condition (above diagonal).

\begin{tabular}{ccccccccc}
\hline & G\% & CL & RL & CL/RL & CDW & RDW & CDW/RDW \\
\hline $\mathrm{G}$ & & $0.25^{* *}$ & $0.37^{* *}$ & $-0.20^{* *}$ & $0.50^{* *}$ & $0.58^{* *}$ & $-0.26^{* *}$ \\
\hline $\mathrm{CL}$ & $0.41^{* *}$ & & $0.75^{* *}$ & $0.24^{* *}$ & $0.83^{* *}$ & $0.59^{* *}$ & $0.26^{* *}$ \\
\hline $\mathrm{RL}$ & $0.47^{* *}$ & $0.40^{* *}$ & & $-0.30^{* *}$ & $0.70^{* *}$ & $0.74^{* *}$ & $-0.19^{* *}$ \\
\hline $\mathrm{CL} / \mathrm{RL}$ & $0.29^{* *}$ & $0.84^{* *}$ & 0.07 & & 0.10 & $-0.18^{* *}$ & $0.68^{* *}$ \\
\hline $\mathrm{CDW}$ & $0.50^{* *}$ & $0.85^{* *}$ & $0.38^{* *}$ & $0.66^{* *}$ & & $0.76^{* *}$ & $0.18^{* *}$ \\
\hline $\mathrm{RDW}$ & $0.74^{* *}$ & $0.41^{* *}$ & $0.60^{* *}$ & $0.22^{* *}$ & $0.52^{* *}$ & $-0.34^{* *}$ \\
\hline $\mathrm{CDW} / \mathrm{RDW}$ & $0.26^{* *}$ & $0.84^{* *}$ & $0.14^{*}$ & $0.90^{* *}$ & $0.75^{* *}$ & $0.17^{* *}$ & \\
\hline $\mathrm{C} \%$
\end{tabular}

$\mathrm{G} \%=$ germination, $\mathrm{CL}=$ coleoptile length, $\mathrm{RL}=$ root length, $\mathrm{CL} / \mathrm{RL}=$ coleoptile length/root length ratio, $\mathrm{CDW}=$ coleoptile dry weight, $\mathrm{RDW}=$ root dry weight, $\mathrm{CDW} / \mathrm{RDW}=$ coleoptile dry weight $/$ root dry weight ratio. ${ }^{*},{ }^{* *}$ Significant at $p=0.05$ and 0.01 respectively.

Under water stress conditions, all correlations between germination (G\%) and establishment related-traits were significant $(p<0.01)$ and positive, and germination $(\mathrm{G} \%)$ was highly correlated with root dry weight $(\mathrm{RDW})(\mathrm{r}=0.74)$. Coleoptile length $(\mathrm{CL})$ was highly correlated with coleoptile dry weight $(\mathrm{CDW})(\mathrm{r}=0.85)$, and with the ratios coleoptile length/root length (CL/RL) $(r=0.84)$ and coleoptile dry weight/root dry weight $(\mathrm{CDW} / \mathrm{RDW})(\mathrm{r}=0.84)$. Other strong positive correlations were observed between the ratios coleoptile dry weight/root dry weight (CDW/RDW) and coleoptile length/root length $(C L / R L)(r=0.90)$, and coleoptile dry weight $(C D W)(r=0.75)$.

Correlations differed between drought and control conditions, particularly between germination and CL/CR, germination and CDW/RDW, RDW and CL/RL, CDW/RDW and RL. Between CDW/RDW and RDW, the correlation was positive under drought and negative under control conditions. The correlation between CDW and CL/RL was significant under drought and not significant under control conditions. Conversely, between $\mathrm{CL} / \mathrm{RL}$ and RL, correlation was significant under control and not significant under drought conditions.

\subsection{Genomic Regions Associated with Germination and Seedling Establishment Related Traits}

GWAS analysis of the 420 inbred lines with their eight parents used in the current study was performed to identify the genetic associations with the studied traits. Twentyeight were significantly associated with seedling traits under water stress and 16 SNPs were significantly associated under well-watered conditions $\left(p\right.$ threshold $=2.42 \times 10^{-5}$ ).

In this study, no SNPs were significantly associated with germination and root length under water stress. Three SNPs, distributed on chromosomes 5, 6, and 7, were significantly associated with coleoptile length. The additive effect associated with individual SNPs ranged between 0.76 and 1.62. The SNPs explained between 9 and $14 \%$ of the variance, and the number of homozygous lines with the unfavorable allele was higher than the number of lines with the favorable allele for coleoptile length, except for the QTL on bin 5.05 (Table 3).

Eight SNPs, distributed along the chromosomes 2, 4, 6, and 9, were significantly associated with the ratio of coleoptile length/root length under water stress. The additive effect ranged between 0.07 and $0.14 \mathrm{~cm}$. The percentage of variance explained by individual SNPs ranged from 7 to $16 \%$, and the SNP S9_10122782 reached the highest percentage. The number of homozygous lines with the allele that reduced the ratio was higher than the number of homozygous lines with the allele that increased the ratio (Table 3). 
Table 3. SNPs significantly associated with germination and seedling establishment related traits under water stress obtained with $200 \mathrm{~g} \mathrm{~L}^{-1}$ of Polyethylene glycol 6000. Chromosome position (bin), the number of QTLs, the significance of the association, the number of RILs with favorable and unfavorable alleles, the additive value, and the variance explained by each SNP are included in the table.

\begin{tabular}{|c|c|c|c|c|c|c|c|c|}
\hline $\mathrm{SNP}^{\mathrm{a}}$ & Bin & QTL & $p$ Value $^{\mathrm{b}}$ & Allele ${ }^{c}$ & $\begin{array}{l}\text { Additive } \\
\text { Effect }^{d}\end{array}$ & $\begin{array}{c}\text { Increase/ } \\
\text { Decrease }^{\mathrm{e}}\end{array}$ & $R^{2 \mathrm{f}}$ & $\begin{array}{l}\text { Previous Experiments with } \\
\text { Co-Localizing QTLg }\end{array}$ \\
\hline \multicolumn{9}{|c|}{ Coleoptile length } \\
\hline S5_185498400 & 5.05 & CL5.05 & $1.92 \times 10^{-5}$ & $\mathrm{C} / \mathrm{T}$ & 0.76 & $97 / 87$ & 0.1 & \\
\hline S6_3045454 & 6 & CL6.00 & $2.29 \times 10^{-5}$ & $\mathrm{~A} / \mathrm{G}$ & 1.19 & $20 / 184$ & 0.09 & \\
\hline S7_163929841 & 7.04 & CL7.04 & $2.17 \times 10^{-5}$ & $\mathrm{~A} / \mathrm{G}$ & 1.62 & $11 / 128$ & 0.14 & \\
\hline \multicolumn{9}{|c|}{ Coleoptile length/Root length ratio } \\
\hline S2_6486062 & 2.02 & CL/RL2.02 & $1.51 \times 10^{-5}$ & $\mathrm{~T} / \mathrm{A}$ & 0.1 & $12 / 212$ & 0.08 & \\
\hline S4_206750186 & 4.09 & CL/RL4.09 & $7.41 \times 10^{-6}$ & $\mathrm{C} / \mathrm{A}$ & 0.13 & $7 / 135$ & 0.13 & \\
\hline S4_235381511 & 4.09 & CL/RL4.09 & $8.33 \times 10^{-6}$ & $\mathrm{G} / \mathrm{A}$ & 0.14 & $6 / 126$ & 0.14 & \\
\hline S6_107737617 & 6.04 & CL/RL6.04 & $2.97 \times 10^{-6}$ & $\mathrm{~T} / \mathrm{C}$ & 0.1 & $14 / 234$ & 0.09 & \\
\hline S6_111018551 & 6.04 & 1 & $1.27 \times 10^{-5}$ & $\mathrm{~A} / \mathrm{G}$ & 0.09 & $14 / 250$ & 0.08 & Trampe (2019) \\
\hline S6_114057282 & 6.04 & CL/RL6.04 & $2.05 \times 10^{-5}$ & $\mathrm{~T} / \mathrm{C}$ & 0.07 & $20 / 239$ & 0.07 & \\
\hline S6_114919493 & 6.04 & CL/RL6.04 & $2.11 \times 10^{-5}$ & $\mathrm{~T} / \mathrm{C}$ & 0.08 & $20 / 164$ & 0.09 & \\
\hline S9_10122782 & 9.01 & CL/RL9.01 & $5.31 \times 10^{-7}$ & $\mathrm{~T} / \mathrm{A}$ & 0.12 & $10 / 156$ & 0.16 & \\
\hline \multicolumn{9}{|c|}{ Coleoptile dry weight } \\
\hline S2_55483944 & 2.04 & CDW2.04 & $6.01 \times 10^{-8}$ & $\mathrm{G} / \mathrm{C}$ & 6.97 & $12 / 230$ & 0.13 & \\
\hline S2_56924044 & 2.04 & CDW2.04 & $2.18 \times 10^{-5}$ & $\mathrm{~T} / \mathrm{C}$ & 4.55 & $17 / 256$ & 0.07 & \\
\hline S2_61029060 & 2.04 & CDW2.04 & $1.44 \times 10^{-5}$ & $\mathrm{~A} / \mathrm{C}$ & 5.28 & $13 / 241$ & 0.08 & \\
\hline S5_11084653 & 5.02 & CDW5.02 & $1.51 \times 10^{-5}$ & $\mathrm{G} / \mathrm{T}$ & 6.42 & $9 / 135$ & 0.16 & \\
\hline S5_214081679 & 5.08 & CDW5.08 & $7.67 \times 10^{-6}$ & $\mathrm{~T} / \mathrm{A}$ & 5.93 & $12 / 122$ & 0.13 & \\
\hline S6_3042595 & 6 & CDW6.00 & $7.55 \times 10^{-7}$ & $\mathrm{G} / \mathrm{A}$ & 6.29 & $13 / 153$ & 0.13 & \\
\hline S6_157412647 & 6.06 & CDW6.06 & $9.23 \times 10^{-7}$ & $\mathrm{~T} / \mathrm{G}$ & 7.12 & $10 / 127$ & 0.15 & \\
\hline S8_145231325 & 8.05 & CDW8.05 & $2.79 \times 10^{-6}$ & $\mathrm{~T} / \mathrm{G}$ & 6.61 & $10 / 191$ & 0.11 & \\
\hline S8_163741873 & 8.06 & CDW8.06 & $4.82 \times 10^{-6}$ & $\mathrm{C} / \mathrm{T}$ & 3.68 & $25 / 174$ & 0.11 & \\
\hline S8_164558505 & 8.06 & CDW8.06 & $6.55 \times 10^{-7}$ & $\mathrm{~A} / \mathrm{G}$ & 6.87 & $11 / 138$ & 0.14 & \\
\hline \multicolumn{9}{|c|}{ Root dry weight } \\
\hline S3_10685613 & 3.03 & RDW3.03 & $1.18 \times 10^{-5}$ & $\mathrm{~A} / \mathrm{C}$ & 2.68 & $73 / 116$ & 0.1 & \\
\hline S10_127256724 & 10 & RDW10.00 & $1.47 \times 10^{-5}$ & $\mathrm{~A} / \mathrm{G}$ & 3 & $51 / 119$ & 0.11 & \\
\hline \multicolumn{9}{|c|}{ Coleoptile dry weight/Root dry weight ratio } \\
\hline S1_82154624 & 1.04 & CDW/RDW1.04 & $1.48 \times 10^{-5}$ & $\mathrm{G} / \mathrm{A}$ & 0.52 & $6 / 127$ & 0.14 & \\
\hline S2_216786049 & 2.08 & CDW / RDW2.08 & $1.79 \times 10^{-5}$ & $\mathrm{~T} / \mathrm{G}$ & 0.48 & $7 / 147$ & 0.11 & \\
\hline S2_217507453 & 2.08 & CDW/RDW2.08 & $6.87 \times 10^{-6}$ & $\mathrm{~T} / \mathrm{A}$ & 0.52 & $7 / 118$ & 0.15 & \\
\hline S2_218777697 & 2.08 & CDW/RDW2.08 & $3.85 \times 10^{-6}$ & $\mathrm{~A} / \mathrm{G}$ & 0.41 & $11 / 193$ & 0.1 & \\
\hline S9_10122782 & 9.01 & CDW/RDW9.01 & $1.48 \times 10^{-5}$ & $\mathrm{~T} / \mathrm{A}$ & 0.41 & $10 / 153$ & 0.12 & \\
\hline
\end{tabular}

a The number before the underscore $\left(\_\right)$indicates the chromosome number and the number after the underscore $\left(\_\right)$indicates the physical position of the SNP in bp within the chromosome. ${ }^{b}$ The significance threshold based on the deviation of $\mathrm{F}$ observed from expected is $p=1 \times 10^{-4} .{ }^{\mathrm{c}}$ The allele before the slash $(/)$ increases the trait and the allele after the slash decreases the trait. ${ }^{\mathrm{d}}$ The additive effect was calculated as half the difference between the mean number of homozygotes for the allele that increases the trait and the mean number of the allele that decreases it. ${ }^{e}$ Number of homozygous lines for a given variant. The number before the slash refers to the allele that increases the trait and the number after the slash to the allele that decreases the trait. ${ }^{\mathrm{f}} R^{2}$, proportion of the phenotypic variance explained by the SNP.

Ten SNPs distributed along the chromosomes 2, 5, 6, and 8 were significantly associated with coleoptile dry weight, with three in bin 2.04 and two in bin 8.06. The additive effect for individual SNPs ranged between 3.68 and $6.97 \mathrm{~cm}$, and the SNPs explained between 7 and $16 \%$ of the variance, and the highest value was reached by S5_11084653. 
The number of homozygous lines with the unfavorable allele was higher than the number of homozygous lines with the favorable allele for the trait (Table 3).

The two SNPs, S3_10685613 and S10_127256724, on chromosome 3 and 10, respectively, were significantly associated with root dry weight under water stress, with an additive value of 2.68 and 3, respectively, and the percentage of variance was 10 and $11 \%$. The number of homozygous lines with the unfavorable allele was higher than the number of homozygous lines with the favorable allele (Table 3).

Five SNPs distributed along chromosomes 1, 2, and 9, were significantly associated with coleoptile dry weight/root dry weight ratio under water stress, with three of them in bin 2.08. Three SNPs were found on chromosome 2. The additive value associated with individual SNPs ranged from 0.41 to $0.52 \mathrm{~cm}$ and the percentage of variance ranged between 10 and $15 \%$. The number of homozygous lines with the unfavorable allele was higher than the number of homozygous lines with the favorable allele (Table 3).

Under well-watered conditions, no SNPs were found to be significantly associated with root length, root dry weight, and coleoptile dry weight/root dry weight ratio. Three SNPs distributed on the chromosomes 1 and 4 were significantly associated with germination in this treatment, and the SNPs S4_18695379 and S4_18695411 in bin 4.03 were close. The additive effect associated with individual SNPs ranged between 8.27 and $13.06 \mathrm{~cm}$ (shared between the two SNPs on chromosome 4), and the percentage of variance ranged from 12 to $15 \%$ (shared between the two SNPs on chromosome 4). The number of homozygous lines with the favorable allele was higher than the homozygous lines with the unfavorable allele (Table 4).

Table 4. SNPs significantly associated with germination and seedling establishment-related traits under well-watered conditions. Chromosome position (bin), the number of QTLs, the significance of the association, the number of RILs with favorable and unfavorable alleles, the additive value, and the variance explained by each SNP are included in the table.

\begin{tabular}{|c|c|c|c|c|c|c|c|c|}
\hline $\mathrm{SNP}^{\mathrm{a}}$ & Bin & QTL & $p$ Value $^{b}$ & Allele ${ }^{\mathrm{c}}$ & $\begin{array}{l}\text { Additive } \\
\text { Effect }\end{array}$ & $\begin{array}{c}\text { Increase/ }^{\text {Decrease }} \\
\text { De }^{\mathrm{e}}\end{array}$ & $R^{2 \mathrm{f}}$ & $\begin{array}{l}\text { Previous Experiments with } \\
\text { Co-Localizing QTLg }\end{array}$ \\
\hline \multicolumn{9}{|c|}{ Germination } \\
\hline S1_281709337 & 1.1 & G1.1 & $6.63 \times 10^{-6}$ & $\mathrm{~A} / \mathrm{T}$ & 8.27 & $116 / 31$ & 0.15 & \\
\hline S4_18695379 & 4.03 & G4.03 & $8.67 \times 10^{-7}$ & $\mathrm{C} / \mathrm{T}$ & 13.06 & $209 / 12$ & 0.12 & \\
\hline S4_18695411 & 4.03 & G4.03 & $8.67 \times 10^{-7}$ & $\mathrm{C} / \mathrm{G}$ & 13.06 & $209 / 12$ & 0.12 & \\
\hline \multicolumn{9}{|c|}{ Coleoptile length } \\
\hline S6_158689148 & 6.06 & CL6.06 & $1.74 \times 10^{-5}$ & $\mathrm{C} / \mathrm{T}$ & 3.82 & $32 / 141$ & 0.12 & \\
\hline \multicolumn{9}{|c|}{ Coleoptile length/Root length ratio } \\
\hline S1_42298404 & 1.03 & CL/RL1.03 & $4.38 \times 10^{-6}$ & $\mathrm{~A} / \mathrm{C}$ & 0.19 & $9 / 165$ & 0.1 & \\
\hline S1_279913636 & 1.1 & CL/RL1.1 & $1.38 \times 10^{-5}$ & $\mathrm{C} / \mathrm{G}$ & 0.15 & $14 / 130$ & 0.11 & \\
\hline S2_19259124 & 2.03 & CL/RL2.03 & $1.28 \times 10^{-7}$ & $\mathrm{G} / \mathrm{A}$ & 0.22 & $10 / 197$ & 0.12 & \\
\hline S3_165855897 & 3.05 & CL/RL3.05 & $1.22 \times 10^{-5}$ & $\mathrm{~A} / \mathrm{G}$ & 0.2 & $8 / 149$ & 0.12 & \\
\hline S6_62741341 & 6.01 & CL/RL6.01 & $2.29 \times 10^{-5}$ & $\mathrm{G} / \mathrm{C}$ & 0.11 & $32 / 218$ & 0.12 & \\
\hline S7_140235159 & 7.03 & CL/RL7.03 & $1.11 \times 10^{-6}$ & $\mathrm{C} / \mathrm{T}$ & 0.16 & $11 / 168$ & 0.1 & \\
\hline S7_161684211 & 7.04 & CL/RL7.04 & $1.40 \times 10^{-5}$ & $\mathrm{~A} / \mathrm{G}$ & 0.13 & $23 / 109$ & 0.07 & \\
\hline S8_13332626 & 8.02 & CL/RL8.02 & $1.64 \times 10^{-5}$ & $\mathrm{~A} / \mathrm{C}$ & 0.22 & $7 / 129$ & 0.14 & \\
\hline S8_159549553 & 8.06 & CL/RL8.06 & $8.90 \times 10^{-6}$ & $\mathrm{~A} / \mathrm{T}$ & 0.12 & $20 / 232$ & 0.12 & \\
\hline S8_171777809 & 8.08 & CL/RL8.08 & $9.84 \times 10^{-6}$ & $\mathrm{C} / \mathrm{G}$ & 0.27 & $5 / 122$ & 0.12 & \\
\hline S10_18140694 & 10.03 & CL/RL10.03 & $5.14 \times 10^{-6}$ & $\mathrm{~A} / \mathrm{C}$ & 0.19 & $9 / 165$ & 0.13 & \\
\hline \multicolumn{9}{|c|}{ Coleoptile dry weight } \\
\hline S7_140235159 & 7.03 & CDW7.03 & $1.17 \times 10^{-5}$ & $\mathrm{~A} / \mathrm{G}$ & 0.36 & $28 / 183$ & 0.09 & \\
\hline
\end{tabular}

a The number before the underscore (_) indicates the chromosome number and the number after the underscore (_) indicates the physical position of the SNP in bp within the chromosome. ${ }^{b}$ The significance threshold based on the deviation of $\mathrm{F}$ observed from expected is $p=1 \times 10^{-4}$. ${ }^{\mathrm{c}}$ The allele before the slash $(/)$ increases the trait and the allele after the slash decreases the trait. ${ }^{\mathrm{d}}$ The additive effect was calculated as half the difference between the mean number of homozygotes for the allele that increases the trait and the mean number of the allele that decreases it. ${ }^{\mathrm{e}}$ Obs $=$ number of homozygous lines for a given variant. The number before the slash refers to the allele that increases the trait and the number after the slash to the allele that decreases the trait. ${ }^{\mathrm{f}} R^{2}$, proportion of the phenotypic variance explained by the SNP. 
Only one SNP on the chromosome 6 was significantly associated with coleoptile length, with an additive value of 3.82, where the percentage of variance explained with this SNP was $12 \%$. The number of homozygous lines with the favorable allele was lower than the number of lines with the unfavorable allele (Table 4).

Eleven SNPs distributed along the chromosomes, with the exception of chromosomes 4,5 , and 9, were significantly associated with the coleoptile length/root length ratio. The additive value ranged from 0.11 to $0.27 \mathrm{~cm}$ and the SNPs S8_171777809 had the higher value (0.27). The percentage of variance explained between 7 and $14 \%$. The number of homozygous lines with the favorable allele was lower than the number of homozygous lines with the unfavorable allele (Table 4).

One SNP located on the chromosome 7, S7_140235159, was significantly associated with coleoptile dry weight. The additive value of this SNP was $0.36 \mathrm{~cm}$ and the percentage of variance explained by this SNP was 9\%. The number of homozygous lines with the favorable allele was lower than the number of homozygous lines with the unfavorable allele (Table 4).

Some SNPs were associated with two traits; specifically, under drought stress, the SNP S9_10122782, located in bin 9.01 and associated with coleoptile dry weight/root dry weight ratio, was also associated with coleoptile length/root length ratio. The SNP S6_3045454 located in in bin 6.00 was associated with coleoptile length and was very close to S6_3042595, which was associated with coleoptile dry weight. Finally, under control conditions, S7_140235159, in bin 7.03, was associated with coleoptile length/root length ratio and coleoptile dry weight.

\subsection{Candidate Genes Described in the Regions Surrounding Significant SNP}

Based on the maize genome reference, a list of candidate genes was retrieved within an interval of $700 \mathrm{kbp}$ upstream and downstream from the significant SNP. We considered as candidate genes those genes previously reported in the $700 \mathrm{kbp}$ interval of each SNP significantly associated with a trait, which had some potential relationship with the trait associated with the significant SNP, based on the described function of the gene. There were 1566 candidate genes associated with all traits under wellwatered (631) and stress (935) conditions. The most significant of these are reported in Supplementary Tables S1 and S2.

Under well-watered conditions, there were 71 candidate genes associated with germination in chromosomes 1 and 4, and 67 candidate genes associated with coleoptile length in chromosome 6 . Coleoptile length/root length ratio had the highest number (457) of candidate genes under well-watered conditions in chromosomes 1, 2, 3, 6, 7, 8, and 10. In addition, there were 36 candidate genes associated with coleoptile dry weight in chromosome 7 (Supplementary Table S1).

Under water stress conditions, 70 candidate genes were associated with coleoptile length in chromosomes 5, 6, and 7. There were 367 candidate genes for coleoptile dry weight in chromosomes 2, 5, 6, and 8. For coleoptile length/root length ratio, there were 261 candidate genes in chromosomes 2, 4, 6, and 9. There were 170 candidate genes associated with coleoptile dry weight/root dry weight ratio in chromosomes 1, 2, and 9 . Finally, 67 candidate genes were associated with root dry weight in chromosomes 3 and 10 (Supplementary Table S2).

Among these candidate genes, only those related to drought stress, germination, and seedling traits are detailed in the Discussion section. The candidate genes detected under water stress and well-watered conditions involved in other stresses and biological processes are listed with their implications in Supplementary Tables S1 and S2.

\section{Discussion}

Drought is a serious agronomic problem and one of the most important factors limiting maize biomass and seed production in almost all areas where it is grown. As a 
quantitative trait, it requires an understanding of genetic mechanisms controlling various plant responses for adopting different breeding approaches [29].

In this study, drought was simulated through the solution of Polyethylene glycol (PEG). PEG-induced drought decreases water uptake and thus germination, which becomes either delayed or occurs at a reduced rate [47]. In a previous study conducted by Djemel et al. [48], the applied stress ( $200 \mathrm{~g} / \mathrm{L}$ of Polyethylene glycol) had the highest effect on germination indexes in the temperate maize germplasm [48].

The RILS used in the current study showed a wide range of phenotypic variation at the early developmental stage in response to drought-induced stress. The applied drought stress treatment clearly exerted a negative impact on germination and seedling performance of all maize inbred lines by retarding shoot and root-related traits compared to the control. This is in agreement with the observations of Ali et al. [49] and Khan et al. [42].

In previous studies, the MAGIC population used here allowed a finer dissection of the genetics of maize resistance to corn borers and a strong detection of candidate genes based on functional information [50-54].

The targeted phenotypic traits are considered important for the study of drought tolerance at seedling stage and in breeding programs. The germination percentage is the most representative trait at this stage, as noted by Grzesiak et al. [55]. The germination rate under drought stress can indicate the germination ability of drought resistance of various varieties and lines, and root length and density are good indicators of drought tolerance in cultivated crops [56]. The root-shoot ratio has been identified as an important trait indicator of drought tolerance in maize [57]. Avramova et al. [34] identified total root length and shoot dry weight as being reliable measurements of drought tolerance at the seedling stage under field conditions in maize.

These traits have been used in several studies for selection and screening under drought at the seedling stage in maize. The principal effect of a water deficit imposed by drought is impaired germination, resulting in poor plant stand at the early seedling phase and hampering early crop establishment [58]. Li et al. [36] and Naveed et al. [37] explained that, although both shoot and root growth were inhibited by drought stress, shoot growth was more sensitive than root growth. Thus, the shoot-root ratio was typically reduced, which is consistent with our results and those of Ruta et al. [39]. This implies that, under drought stress, plants allocate more resources to root development than to shoot development in order to enhance water acquisition and limit evaporation [59]. Liu et al. [30] reported that, from a physiological perspective, a high root-shoot ratio is, in general, beneficial to tolerate drought stress. Shao et al. [60] associated the reduction in seedling growth to a restricted cell division and enlargement, because drought stress directly reduces growth by decreasing cell division and elongation.

Our results revealed associations between germination and other seedling traits, through significant correlations obtained between germination and targeted traits. Radić et al. [61] noted that poor maize seed germination is directly associated with poor post germination performance. Aslam et al. [62] also confirmed this finding. These data show that drought stress has a clear impact on seed germination and growth and other performance-related traits in maize, although the detrimental effects varied among traits and there was notable variation among genotypes for response to drought.

In the present study, GWAS was carried out on maize inbred lines phenotyped for root and coleoptile-related traits under drought and well-watered conditions, in order to detect SNPs and genomic regions involved in drought tolerance, and thus identify candidate genes which underlie our traits of interest. Some SNPs showed clear pleiotropy with other traits, which is consistent with the significantly positive correlations between the phenotypes. Under stress conditions, the SNP S9_10122782 was significantly associated with the two traits CDW/RDW and CL/RL, which is consistent with the high and significantly positive correlations observed between these traits $(\mathrm{r}=0.90)$. In addition, the SNP S6_3045454, associated with CL, was very close to S6_3042595, associated with CDW, and these traits were also highly correlated $(r=0.83)$. Under well-watered conditions, the 
SNP S7_140235159 was significantly associated with CDW/RDW and CL/RL, which is consistent with the significant and positive correlations between the traits $(r=0.68)$.

The density of SNPs detected in our work varied among chromosomes; the maximum number of SNPs were found on chromosome 6 (nine SNPs) and chromosome 2 (eight SNPs) for all the traits under well-watered and drought conditions. This may increase the interest in these genomic regions for future research. On chromosome 6, the SNP S6_111018551 associated with coleoptile length/root length ratio under drought stress conditions in our study, was detected in a QTL region in a previous study conducted by Trampe [63] using an F2:3 population derived from inbred A427 and CR1Ht. The QTL region spans markers S6_111018551-S6_111368312 at $82 \mathrm{~cm}$, and the QTL showed a pleiotropic effect for anther emergence, pollen production, tassel size, and haploid male fertility.

On chromosome 2, the SNPs S2_55483944, S2_56924044, and S2_61029060 significantly associated with coleoptile dry weight under water stress conditions were located in the chromosomal region (Bin 2.04) where the root-ABA1 QTL is also located [64]. This exerts an important effect on L-abscisic acid and stomatal conductance, influences root lodging through a constitutive effect on root architecture [64], and affects grain yield [65].

Yi et al. [52] studied QTLs for germination and seedling traits in the same MAGIC population under control and cold conditions, and found QTLs for some traits close to those found in our current results. Under drought conditions, we found a QTL for coleoptile/root length ratio in bin 2.02, and Yi et al. [52] reported an important concentration of SNPs associated with early vigor, chlorophyll content, and efficiency of photosystem II under cold conditions. Bin 2.04 had several QTLs for efficiency of photosystem II under cold conditions close to the QTL in the current coleoptile dry weight. Bin 5.05 had an SNP associated with chlorophyll under cold conditions, at least one million databases from the QTLs associated with coleoptile length in the current study. Bin 6.04 had a QTL for chlorophyll under cold conditions close to the QTL for coleoptile/root length ratio found here. These similitudes could indicate common genetic regulation for early plant development under drought and cold stresses. The co-localizations were fewer under control conditions. We detected a QTL for coleoptile/root length in bin 3.05 and Yi et al. [52] reported two close QTLs for chlorophyll under control conditions. However, although Yi et al. [52] found hundreds of QTLs, no other reliable co-localizations were identified, particularly under control conditions.

Based on the maize genome reference, several candidate genes were identified close to the SNPs significantly associated with the traits. Among these candidates, there were those related to biotic and abiotic stresses, growth, plant development, and biological processes. Here, we highlight the genes involved in germination and seedling development under abiotic stresses, particularly drought stress. Others, with their implications, are noted in the Supplementary Tables S1 and S2.

The candidate gene Zm00001d035993, associated with the ratio CL/RL, and Zm00001d021163, associated with CDW, under well-watered conditions, and Zm00001d022079 associated with CL and Zm00001d007251 associated with the ratio CDW/ RDW under drought conditions, belong to the nucleobase cation symporter 2 (NCS2) gene family. NCS2 genes in maize are involved in diverse developmental processes and responses to abiotic stresses, including abscisic acid, salt $(\mathrm{NaCl})$, Polyethylene glycol, and low $\left(4^{\circ} \mathrm{C}\right)$ and high $\left(42{ }^{\circ} \mathrm{C}\right)$ temperatures. These genes are important for the transport of free nucleobases, participating in diverse plant growth and developmental processes, and response to abiotic stress [66].

Under well-watered conditions, the genes Zm00001d038676 and Zm00001d038695 were identified as candidates for coleoptile length in our study. Zm00001d038676 was expressed in a drought tolerant maize mutant (C7-2t) implicated in cell wall enrichment conferring drought resistance [67]. In a study conducted by Wang et al. [68], the gene Zm00001d038695 (gibberellin 2-oxidase) was up-regulated after heat stress; this is related to gibberellin acid (GA) biosynthesis, which increased after heat stress. Gibberellin acid 
hormones were involved in the heat stress response of young ears and had a significant adverse effect on their development.

Many candidate genes were associated with coleoptile length/root length ratio under well-watered conditions. In Li et al. [69], the gene Zm00001d034129 (Peroxidase 73) was associated with maize seedling leaves under cold and heat stress. The authors reported that common genes for both treatments were enriched in the hydrogen peroxidase metabolic process, which is the case of this gene. A MYB family protein member Zm00001d034160 is involved in modulating early nitrate responses in maize through the mechanism of alternative splicing (AS), which plays an important role in maize to adapt to nitrate fluctuation [70]. Zm00001d002707 was annotated as cis-zeatin O-glucosyltransferase with specificity to cis-zeatin, which contributes to the highly active cytokinin pool by inducing transisomers expression; this gene is highly similar to Evm.model.chr7.511, which exhibited a higher expression in the root of temperate lotus [71]. Zm00001d012641 is a key gene involved in biotic and abiotic stresses, and is also related to zeatin biosynthesis, which was down-regulated under heat stress. In the study of Wang et al. [68], the endogenous hormone content, such as zeatin (ZT) in young ears, decreased significantly.

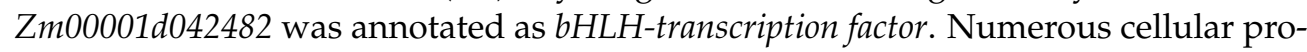
cesses and responses that are important for plants to tolerate various abiotic stresses are controlled by $b H L H$, which is a large family of conserved transcription factors [72]. The gene Zm00001d021961 was annotated as acetylcholinesterase1 (ACHE1). Native tropical zone plants show high acetylcholinesterase $(A C h E)$ activity during heat stress, and $A C h E$ activity in endodermal cells of maize seedlings is increased by heat treatment. Maize $A C h E$ is mainly expressed in coleoptile nodes and seeds. Enhanced maize $A C h E$ activity was observed after heat stress suggesting, that $A C h E$ plays a positive role in maize heat tolerance [73].

Zm00001d008569 (CL/RL) (Delta(7)-sterol-C5(6)-desaturase 1) was a homolog of Os01g0134500 in rice. This candidate gene is involved in brassinosteroid metabolism and was associated with various metaxylem vessel area-related phenotypes under wellwatered conditions in maize and strongly associated with root metaxylem traits [74]. An impairment of its activity is linked to defective longitudinal growth, irregularly spaced vascular bundles, and reduced xylem vessel size and number [74].

A drought-responsive gene, Zm00001d036003, was detected under well-watered conditions and associated with the CL/RL ratio in our study. This gene belongs to the ERF family, genes of which are important regulators involved in cold and heat stresses. This gene was up-regulated under cold and heat conditions in Li et al. [69].

Under drought conditions, three genes involved in the ROS (Reactive Oxygen Species) scavenging system were detected. Zm00001d017240, which was associated with CL and is a Grx-like gene improving the stability of the plasma membrane biochemical process related to proline metabolism, was up-regulated in transgenic maize, enhancing drought tolerance. We conclude this gene may play an important role in ROS detoxification enzyme activity under drought stress [75]. Zm00001d003797, which was associated with CDW (Ferredoxin-3 chloroplastic), is a specific drought-responsive protein of the Sorghum bicolor genotype, RTx430 (preflowering drought-tolerant genotype), and is involved in the production of ROS scavenging ferredoxins, a mechanism of drought tolerance [76]. Zm00001d037079, which was associated with $\mathrm{CL} / \mathrm{RL}$, was down-regulated at the third leaf stage after waterlogging for 6 days [77].

The genes Zm00001d017251 (fatty aldehyde decarbonylase) associated with CL and Zm00001d039631 associated with RDW, implicated in suberine, wax, and cutin biosynthesis, were also detected, Zm00001d017251 was up-regulated after drought stress during the juvenile phase of the maize plant growth. Zm00001d039631 has a role in binding and transport of the fatty acid, cutin, and wax monomers, and was also up-regulated after 2 days of drought [78]. In genes involved in wax biosynthesis, the total amount of cuticular wax is increased in response to drought stress conditions, thus improving plant protection from 
water loss [78]. Relevant genes related to cell wall biosynthesis confirm the importance of the cell wall structure and composition in resistance to drought.

Zm00001d017258 associated with CL was identified as an important TCA (tricarboxylic acid) gene overexpressed in Arabidopsis and associated with root development. The overexpression of this gene significantly shortened the length of the primary root of Arabidopsis, suggesting that elevated expression levels of these TCA cycle genes may cause certain negative effects on mitochondria and ultimately inhibit root growth [79].

The detected drought-responsive gene, Zm00001d003850, was associated with CDW (Putative BOI-related E3 ubiquitin-protein ligase 2). This is a specific gene of the tolerant line YE8112 in maize; it was up-regulated under water stress and encoding proteins involved in ubiquitination [80]. Protein ubiquitination has been widely recognized as a central regulator of stress responsive transcription factors and other regulatory proteins, effectively contributing to abiotic stress adaptation [81]. Zm00001d002126 was associated with CL/RL and down-regulated in a drought-tolerant inbred line [80] Zm00001d002199 receptor-like serine/threonine-protein kinase was identified as a hub-gene. Receptor kinases, another vital type of membrane protein, was found to be differentially expressed in response to drought stress in maize [82]. Zm00001d037273 was associated with the CL/RL ratio and implicated in heat stress response (HSR). Jagtap et al. [83] detected Zm00001d007215 in hybrids tolerant to water stress during the maize kernel-filling stage in a previous study. This is a differentially abundant proteins $(D A P)$ gene involved in the response to drought stress [84]. Zm00001d029707 was associated with CDW/RDW and is a GST gene induced and up-regulated after heat stress [70].

$\mathrm{Zm} 00001 \mathrm{~d} 011406$, which is a candidate for CDW, is a transcription factor belonging to the HSFTF (Heat Shock Factor transcription factor) family, was downregulated in response to ABA [85]. Heat shock transcription factor ( $H s f)$ plays a transcriptional regulatory role in plants during heat stress and other abiotic stresses [86].

Two other candidate genes controlling CL/RL ratio were Zm00001d002143, which was associated with phenylpropanoid biosynthesis, a stress-responsive pathway [87], and Zm00001d037112, encoding a root-specific kinase protein, which was associated with abiotic stress responses in Rogers and Benfey [88].

Zm00001d007229, a candidate for CDW/RDW, belongs to the PLC (Phospholipase C family) gene family in maize. PLC is one of the main hydrolytic enzymes in the metabolism of phosphoinositide and plays an important role in a variety of signal transduction processes responding to plant growth, development, and stress [89]. The functional annotation of these genes in maize confirms the role of these candidates with regard to drought tolerance at the germination and early seedling development stage.

Genes involved in both heat and cold stresses were found to be associated with the CDW/RDW ratio. Zm00001d007181 encoding CML (CaM-like proteins), was upregulated under both cold and heat stress [70] and Zm00001d007267, which was mainly involved in photosynthesis, is a candidate gene identified as a possible hub gene involved in temperature stresses [69].

Genes implicated in waterlogging tolerance were detected. Zm00001d022084, which is a candidate for $\mathrm{CL}$, was up-regulated under flooding conditions in maize. It was observed that the rice orthologue was also up-regulated under the same conditions, and this gene is implicated in flooding tolerance during seed germination and early seedling growth in rice [90]. Zm00001d012103, associated with CDW encoding of aldolase2, and involved in the glycolysis/gluconeogenesis pathway, which produces energy and recycles carbon for other pathways to survive, was found to be up-regulated, indicating this pathway's underlying central role in waterlogging stress in early, late, and long-term responses [91]. Zm00001d007161, which was associated with the ratio CDW/RDW encoding peroxidase, is involved in response to waterlogging stress in maize roots [91].

Within the genes associated with our traits of interest under water stress, there were those implicated in salt, aluminum, and phosphorus stresses according to previous studies (Supplementary Table S1). 


\section{Materials and Methods}

\subsection{Plant Material}

The maize multi-parent advanced generation inter-cross (MAGIC) population used in this study was established by the Maize Genetics and Breeding Group of the Misión Biológica de Galicia, CSIC (Pontevedra, Spain), with eight diverse founder lines, with a heterogeneous background [50,51] (Table 5). We evaluated 420 recombinant inbred lines (RILS) of the MAGIC population together with the eight parents for drought tolerance. The genotypes were phenotyped at germination and during seedling development, under control and water stress conditions imposed using aqueous solutions of high molecular weight Polyethylene glycol 6000 (PEG 6000) according to the method described by ÁlvarezIglesias et al. [41].

Table 5. Parental lines of the MAGIC population evaluated in this study.

\begin{tabular}{|c|c|c|c|}
\hline Lines & Grain Color & Pedigree & Type of Grain \\
\hline $\mathrm{EP} 17^{\mathrm{a}}$ & Yellow & A1267 (Unknown location) ${ }^{\mathrm{e}}$ & Flint \\
\hline $\mathrm{EP} 43^{\mathrm{a}}$ & Yellow & Parderrubias (Atlantic Spain) ${ }^{\mathrm{e}}$ & Flint \\
\hline $\mathrm{EP}^{2} 3^{\mathrm{a}}$ & Yellow & Laro (Atlantic Spain) ${ }^{\mathrm{e}}$ & Flint \\
\hline EP86 $^{\mathrm{a}}$ & Yellow & Nostrano dell'Isola (Italy) $^{\mathrm{e}}$ & Flint \\
\hline PB130 ${ }^{b}$ & Yellow & $\begin{array}{l}\text { Rojo Vinoso de Aragón } \\
\text { (Mediterranean Spain) e }\end{array}$ & Flint \\
\hline $\mathrm{F} 473^{\mathrm{c}}$ & White & Doré de Gomer (France) ${ }^{\mathrm{e}}$ & Flint \\
\hline EP125 a & Yellow & Selection from CO125 & Corn Belt Dent \\
\hline $\mathrm{A} 509^{\mathrm{d}}$ & Yellow & A78 $\times$ A109 & Corn Belt Dent \\
\hline
\end{tabular}

a From Misión Biológica de Galicia (Spain). ${ }^{\mathrm{b}}$ From Estacão Agraria de Braga (Portugal). ${ }^{\mathrm{c}}$ From Institut National de la Recherche Agronomique (France). ${ }^{d}$ From University of Minnesota (USA). ${ }^{e}$ European landrace.

\subsection{Experimental Design and Data Recorded}

The evaluation of seed germination under water stress conditions was conducted in Petri dishes by placing 10 seeds of each maize recombinant inbred line on a Whatman filter paper layer moistened with $10 \mathrm{~mL}$ of PEG 6000 solution with a concentration of $200 \mathrm{~g} / \mathrm{L}$ (considered to be a severe concentration for germination according to Alvarez-Iglesias et al. [41]), and distilled water was used as control. Petri dishes were sealed with parafilm to avoid water loss through evaporation and incubated in the dark at $27^{\circ} \mathrm{C}$ in a growth chamber. The evaluation followed a randomized complete block design (RCBD) with three repetitions.

The number of germinated seeds was counted after 5 days and used to calculate the final germination percentage $(\mathrm{G} \%)$. The primary root and coleoptile lengths (RL, CL) were recorded for all seedlings on each Petri dish. Then, the dry weight (DW) was obtained after drying for $72 \mathrm{~h}$ at $60{ }^{\circ} \mathrm{C}$ of all primary roots, secondary roots, and coleoptiles collected from each Petri dish. From these data, the ratios of coleoptile length/root length (CL/RL) and coleoptile dry weight/root dry weight (CDW/RDW) were calculated.

\subsection{Statistical Analyses}

The recombinant inbred lines derived from the MAGIC population were previously genotyped for 955.690 SNPs using a genotyping-by-sequencing (GBS) strategy. The genotype matrix was filtered as follows: Heterozygous genotypes and insertion/deletion polymorphisms (INDELs) were considered missing data and SNPs with more than $50 \%$ missing data and/or minor allele frequency less than $5 \%$ were omitted. As a result, we obtained a genotype matrix constituted by 215.131 SNPs distributed across the maize genome. The best linear unbiased estimators (BLUEs) for each trait were calculated. For each trait under both irrigation conditions, descriptive statistics (mean, skewness, kurtosis, and coefficient of variation) were calculated. Phenotypic $\left(\mathrm{r}_{\mathrm{p}}\right)$ correlation coefficients among traits under 
both irrigation conditions were calculated using REML estimates according to a SAS mixed model procedure [92]. A genome-wide association analysis was completed with Tassel 5 [93]. The association analysis was based on a mixed linear model (optimum compression level and P3D to estimate the variance components), which included a genotype-phenotype matrix and a kinship matrix built using the centered IBS method [94]. Complete and filtered genotype databases are available as supplementary materials in López-Malvar et al. [54].

\subsection{SNPs, QTL and Candidate Gene Selection}

To calculate the comparison-wise threshold for declaring an association between a trait and a SNP to be significant, we used a modification of the Bonferroni approach [95]. This consists of calculating the number of independent tests by the Haploview program using the option four gamete rules [96,97], resulting in 12,397 independent comparisons. Then, the comparison-wise threshold was the coefficient between the established experimentwise threshold (0.3) and the number of independent tests. Thereby, a marker would be considered significantly associated with a trait at $p$-values less than $2.42 \times 10^{-5}(-\log 10$ $(p$-value $)=4.6)$.

A + / -700 kbp confidence interval region around each significant SNP was considered following previous association studies using the same MAGIC population [52,54]. SNPs were assigned to the same QTL in the case in which its confidence intervals overlapped. For the search of candidate genes associated with the traits under study, we considered the two described genes that delimit the $+/-700 \mathrm{kbp}$ region around the SNP in the reference genome assembly version 2 . We positioned these in version 4 of the reference genome, and all genes contained in that region were then identified and characterized based on the maize B73 reference genome assembly (version 4) available on the MaizeGDB browser [98].

\section{Conclusions}

The present study shows how drought stress can affect seed germination and seedling parameters during early growth. The genomic regions and genes, and the metabolic pathways identified here, can be valuable genetic resources or selection targets for developing new drought-resistant maize cultivars. Some SNPs had significant associations with several traits, suggesting a pleiotropic genetic control. Other SNPs were co-located with QTLs for cold tolerance previously published for this MAGIC population. Several candidate genes, close to the significant SNPs, are related to biotic and abiotic stresses and plant development. These results can be used for improving drought tolerance at the seedling stage in maize in further research to increase the understanding of the genetic architecture of complex traits under drought stress conditions.

Supplementary Materials: The following are available online at https:/ /www.mdpi.com/article/10 $.3390 /$ plants10091786/s1, Table S1: Candidate genes detected under water stress conditions with their implications in previous studies; Table S2: Candidate genes detected under well-watered conditions with their implications in previous studies

Author Contributions: Conceptualization, A.D. and P.R.; methodology, S.R., O.M., M.R.; formal analysis, S.R., A.D. and A.L.-M.; investigation, S.R. and A.D.; resources, A.D. and P.R.; data curation, S.R.; writing—original draft preparation, S.R.; writing—review and editing, A.D., A.L.-M. and P.R.; visualization, A.D.; supervision, A.D. and P.R.; project administration, A.D.; funding acquisition, A.D. All authors have read and agreed to the published version of the manuscript.

Funding: This research was funded by the École Nationale Supérieure Agronomique; PRIMA, a program supported by the European Union under H2020 framework programme; and Spanish Ministerio de Innovación y Universidades (MCIU), the Agencia Estatal de Investigación (AEI) and the European Fund for Regional Development (FEDER), UE (project code PID2019-108127RB-I00). Financial support has been also provided by PRIMA, a program supported by the European Union under the H2020 framework programme and by the project IN607A2021/07 from Xunta de Galicia.

Data Availability Statement: Data are available from the authors upon request. 
Conflicts of Interest: The authors declare no conflict of interest. The funders had no role in the design of the study; in the collection, analyses, or interpretation of data; in the writing of the manuscript, or in the decision to publish the results.

\section{References}

1. Rosenzweig, C.; Elliott, J.; Deryng, D.; Ruane, A.C.; Müller, C.; Arneth, A.; Boote, K.; Folberth, C.; Glotter, M.; Khabarov, N.; et al. Assessing agricultural risks of climate change in the 21st century in a global gridded crop model intercomparison. Proc. Natl. Acad. Sci. USA 2014, 111, 3268-3273. [CrossRef]

2. Harrison, M.T.; Tardieu, F.; Dong, Z.; Messina, C.D.; Hammer, G. Characterizing drought stress and trait influence on maize yield under current and future conditions. Glob. Chang. Biol. 2014, 20, 867-878. [CrossRef] [PubMed]

3. Boyer, J.S.; Byrne, P.; Cassman, K.G.; Cooper, M.; Delmer, D.; Greene, T.; Gruis, F.; Habben, J.; Hausmann, N.; Kenny, N.; et al. The U.S. drought of 2012 in perspective: A call to action. Glob. Food Secur. 2013, 2, 139-143. [CrossRef]

4. Thirunavukkarasu, N.; Hossain, F.; Arora, K.; Sharma, R.; Shiriga, K.; Mittal, S.; Mohan, S.; Namratha, P.M.; Dogga, S.; Rani, T.S.; et al. Functional mechanisms of drought tolerance in subtropical maize (Zea mays L.) identified using genome-wide association mapping. BMC Genom. 2014, 15, 1182. [CrossRef]

5. Lobell, D.; Bänziger, M.; Magorokosho, C.; Vivek, B. Nonlinear heat effects on African maize as evidenced by historical yield trials. Nat. Clim. Chang. 2011, 1, 42-45. [CrossRef]

6. Chen, J.; Xu, W.; Velten, J.; Xin, Z.; Stout, J. Characterization of maize inbred lines for drought and heat tolerance. J. Soil Water Conserv. 2012, 67, 354-364. [CrossRef]

7. Boyer, J.S. Plant productivity and environment. Science 1982, 218, 443-448. [CrossRef]

8. Edmeades, G.O. Drought Tolerance in Maize: An Emerging Reality; Companion Document to Executive Summary ISAAA Briefs 39-2008; ISAAA International Service for the Acquisition of Agri-Biotech Applications: Ithaka, NY, USA, 2008.

9. Webber, H.; Ewert, F.; Olesen, J.E.; Müller, C.; Fronzek, S.; Ruane, A.C.; Bourgault, M.; Martre, P.; Ababaei, B.; Bindi, M.; et al. Diverging importance of drought stress for maize and winter wheat in Europe. Nat. Commun. 2018, 9, 4249. [CrossRef] [PubMed]

10. Edmeades, G.O. Progress in Achieving and Delivering Drought Tolerance in Maize-An Update; ISAA: Ithaka, NY, USA, 2013; pp. $1-44$.

11. Singh, A.; Bhatnagar, N.; Pandey, A.; Pandey, G.K. Plant phospholipase C family: Regulation and functional role in lipid signaling. Cell Calcium 2015, 58, 139-146. [CrossRef]

12. Joshi, R.; Wani, S.; Singh, B.; Bohra, A.; Dar, Z.; Lone, A.; Pareek, A.; Singla-Pareek, S.L. Transcription Factors and Plants Response to Drought Stress: Current Understanding and Future Directions. Front. Plant Sci. 2016, 7, 1029. [CrossRef] [PubMed]

13. Gupta, S.; Kumari, M.; Kumar, H.; Varadwaj, P.K. Genome-wide analysis of miRNAs and Tasi-RNAs in Zea mays in response to phosphate deficiency. Funct. Integr. Genom. 2017, 17, 335-351. [CrossRef] [PubMed]

14. Nakashima, K.; Yamaguchi-Shinozaki, K.; Shinozaki, K. The transcriptional regulatory network in the drought response and its crosstalk in abiotic stress responses including drought, cold, and heat. Front. Plant Sci. 2014, 5, 170. [CrossRef]

15. Stange, M.; Utz, H.F.; Schrag, T.A.; Melchinger, A.E.; Würschum, T. High-density genotyping: An overkill for QTL mapping? Lessons learned from a case study in maize and simulations. Theor. Appl. Genet. 2013, 126, 2563-2574. [CrossRef]

16. Yan, J.; Warburton, M.; Crouch, J. Association Mapping for Enhancing Maize (Zea mays L.) Genetic Improvement. Crop. Sci. 2011, 51, 433-449. [CrossRef]

17. Yan, J.; Shah, T.; Warburton, M.L.; Buckler, E.; McMullen, M.D.; Crouch, J. Genetic characterization and linkage disequilibrium estimation of a global maize collection using SNP markers. PLoS ONE 2009, 4, e8451. [CrossRef] [PubMed]

18. Xiao, Y.; Liu, H.; Wu, L.; Warburton, M.; Yan, J. Genome-wide association studies in maize: Praise and stargaze. Mol. Plant 2017, 10, 359-374. [CrossRef] [PubMed]

19. Buckler, E.S.; Holland, J.B.; Bradbury, P.J.; Acharya, C.B.; Brown, P.J.; Browne, C.; Ersoz, E.; Flint-Garcia, S.; Garcia, A.; Glaubitz, J.C.; et al. The genetic architecture of maize flowering time. Science 2009, 325, 714-718. [CrossRef] [PubMed]

20. Weng, J.; Xie, C.; Hao, Z.; Wang, J.; Liu, C.; Li, M.; Zhang, D.; Bai, L.; Zhang, S.; Li, X. Genome-wide association study identifies candidate genes that affect plant height in chinese elite maize (Zea mays L.) inbred lines. PLoS ONE 2011, 6, e29229. [CrossRef] [PubMed]

21. Li, H.; Peng, Z.; Yang, X.; Wang, W.; Fu, J.; Wang, J.; Han, Y.; Chai, Y.; Guo, T.; Yang, N.; et al. Genome-wide association study dissects the genetic architecture of oil biosynthesis in maize kernels. Nat. Genet. 2013, 45, 43-50. [CrossRef]

22. Tian, F.; Bradbury, P.J.; Brown, P.J.; Hung, H.; Sun, Q.; Flint-Garcia, S.; Rocheford, T.R.; McMullen, M.D.; Holland, J.; Buckler, E. Genome-wide association study of leaf architecture in the maize nested association mapping population. Nat. Genet. 2011, 43, 159-162. [CrossRef]

23. Revilla, P.; Rodríguez, V.M.; Ordás, A.; Rincent, R.; Charcosset, A.; Giauffret, C.; Melchinger, A.E.; Schön, C.-C.; Bauer, E.; Altmann, T.; et al. Association mapping for cold tolerance in two large maize inbred panels. BMC Plant Biol. 2016, 16, 127. [CrossRef]

24. Wang, X.W.H.; Wang, H.; Liu, S.; Ferjani, A.; Li, J.; Yan, J.; Yang, J.L.X.; Qin, F. Genetic variation in ZmVPP1 contributes to drought tolerance in maize seedlings. Nat. Genet. 2016, 48, 1233-1241. [CrossRef] 
25. Xue, Y.; Warburton, M.L.; Sawkins, M.; Zhang, X.; Setter, T.; Xu, Y.; Grudloyma, P.; Gethi, J.; Ribaut, J.-M.; Li, W.; et al. Genomewide association analysis for nine agronomic traits in maize under well-watered and water-stressed conditions. Theor. Appl. Genet. 2013, 126, 2587-2596. [CrossRef]

26. Mackay, T.F.C.; Stone, E.A.; Ayroles, J.F. The genetics of quantitative traits: Challenges and prospects. Nat. Rev. Genet. 2009, 10, 565-577. [CrossRef]

27. Cavanagh, C.; Morell, M.; Mackay, I.; Powell, W. From mutations to magic: Resources for gene discovery, validation and delivery in crop plants. Curr. Opin. Plant Biol. 2008, 11, 215-221. [CrossRef]

28. Flint-Garcia, S.; Thuillet, A.-C.; Yu, J.; Pressoir, G.; Romero, S.M.; Mitchell, S.E.; Doebley, J.; Kresovich, S.; Goodman, M.M.; Buckler, E.S. Maize association population: A high-resolution platform for quantitative trait locus dissection. Plant J. 2005, 44, 1054-1064. [CrossRef]

29. Yordanov, I.; Velikova, V.; Tsonev, T. Plant responses to drought, acclimation, and stress tolerance. Photosynthetica 2000, 38, 171-186. [CrossRef]

30. Muhammad, A.; Amjad, F.; Ihsan, K.; Qurban, A.; Muhammad, A.; Muhammad, K.; Ahsan, M.; Farooq, A.; Khaliq, I.; Ali, Q.; et al. Inheritance of various yield contributing traits in maize (Zea mays L.) at low moisture condition. Afr. J. Agric. Res. 2013, 8, 413-420. [CrossRef]

31. Liu, M.; Li, M.; Liu, K.; Sui, N. Effects of drought stress on seed germination and seedling growth of different maize varieties. J. Agric. Sci. 2015, 7, 231-240. [CrossRef]

32. Zhao, Q. Lignification: Flexibility, Biosynthesis and Regulation. Trends Plant Sci. 2016, 21, 713-721. [CrossRef] [PubMed]

33. Meeks, M.; Murray, S.C.; Hague, S.; Hays, D. Measuring maize seedling drought response in search of tolerant germplasm. Agronomy 2013, 3, 135-147. [CrossRef]

34. Anjum, S.A.; Xie, X.; Wang, L.; Saleem, M.F.; Man, C.; Lei, W. Morphological, physiological and biochemical responses of plants to drought stress. Afr. J. Agric. Res. 2011, 6, 2026-2032. [CrossRef]

35. Avramova, V.; Nagel, K.A.; AbdElgawad, H.; Bustos, D.; DuPlessis, M.; Fiorani, F.; Beemster, G.T. Screening for drought tolerance of maize hybrids by multi-scale analysis of root and shoot traits at the seedling stage. J. Exp. Bot. 2016, 67, 2453-2466. [CrossRef]

36. Kaydan, D.; Yagmur, M. Germination, seedling growth and relative water content of shoot in different seed sizes of triticale under osmotic stress of water and NaCI. Afr. J. Biotechnol. 2008, 7, 2862-2868. [CrossRef]

37. Li, X.; Mu, C.; Lin, J. The germination and seedlings growth response of wheat and corn to drought and low temperature in spring of Northeast China. J. Anim. Plant Sci. 2014, 2121, 3212-3222.

38. Naveed, M.; Mitter, B.; Reichenauer, T.G.; Wieczorek, K.; Sessitsch, A. Increased drought stress resilience of maize through endophytic colonization by Burkholderia phytofirmans PsJN and Enterobacter sp. FD17. Environ. Exp. Bot. 2014, 97, 30-39. [CrossRef]

39. Whitmore, A.P.; Whalley, R. Physical effects of soil drying on roots and crop growth. J. Exp. Bot. 2009, 60, 2845-2857. [CrossRef] [PubMed]

40. Ruta, N.; Stamp, P.; Liedgens, M.; Fracheboud, Y.; Hund, A. Collocations of QTLs for seedling traits and yield components of tropical maize under water stress conditions. Crop Sci. 2010, 50, 1385-1392. [CrossRef]

41. Zhao, F.; Zhang, D.; Zhao, Y.; Wang, W.; Yang, H.; Tai, F.; Li, C.; Hu, X. The difference of physiological and proteomic changes in maize leaves adaptation to drought, heat, and combined both stresses. Front. Plant Sci. 2016, 7, 1471. [CrossRef] [PubMed]

42. Álvarez-Iglesias, L.; de la Roza-Delgado, B.; Reigosa, M.J.; Revilla, P.; Pedrol, N. A simple, fast and accurate screening method to estimate maize (Zea mays L.) tolerance to drought at early stages. Maydica 2018, 62, 12.

43. Khan, N.H.; Ahsan, M.; Naveed, M.; Sadaqat, H.A.; Javed, I. Genetics of drought tolerance at seedling and maturity stages in Zea mays L. Span. J. Agric. Res. 2016, 14, e0705. [CrossRef]

44. Djemel, A.; Cherchali, F.Z.; Benchikh-Le-Hocine, M.; Malvar, R.A.; Revilla, P. Assessment of drought tolerance among Algerian maize populations from oases of the Saharan. Euphytica 2018, 214, 149. [CrossRef]

45. Djemel, A.; Álvarez-Iglesias, L.; Santiago, R.; Malvar, R.A.; Pedrol, N.; Revilla, P. Algerian maize populations from the Sahara desert as potential sources of drought tolerance. Acta Physiol. Plant. 2019, 41, 12. [CrossRef]

46. Badr, A.; El-Shazly, H.H.; Tarawneh, R.A.; Börner, A. Screening for drought tolerance in maize (Zea mays L.) germplasm using germination and seedling traits under simulated drought conditions. Plants 2020, 9, 565. [CrossRef] [PubMed]

47. Zaidi, P.H.; Seetharam, K.; Krishna, G.; Krishnamurthy, L.; Gajanan, S.; Babu, R.; Zerka, M.; Vinayan, M.T.; Vivek, B.S. Genomic regions associated with root traits under drought stress in tropical maize (Zea mays L.). PLoS ONE 2016, 11, e0164340. [CrossRef] [PubMed]

48. Partheeban, C.; Chandrasekhar, C.; Jeyakumar, P.; Ravikesavan, R.; Gnanam, R. Effect of PEG induced drought stress on seed germination and seedling characters of maize (Zea mays L.) genotypes. Int. J. Curr. Microbiol. Appl. Sci. 2017, 6, 1095-1104. [CrossRef]

49. Djemel, A.; Álvarez-Iglesias, L.; Pedrol, N.; López-Malvar, A.; Ordás, A.; Revilla, P. Identification of drought tolerant populations at multi-stage growth phases in temperate maize germplasm. Euphytica 2018, 214, 138. [CrossRef]

50. Ali, Q.; Ahsan, M.; Ali, F.; Muhammad, S.; Manzoor, M.; Khan, N.H.; Maqsood, S.; Basra, A.; Saad, H.; Mustafa, B. Genetic advance, heritability, correlation, heterosis and heterobeltiosis for morphological traits of maize (Zea mays L.). Albanian J. Agric. Sci. 2013, 12, 689-698.

51. Butrón, A.; Santiago, R.; Cao, A.; Samayoa, L.F.; Malvar, R.A. QTLs for resistance to fusarium ear rot in a multiparent advanced generation intercross (MAGIC) maize population. Plant Dis. 2019, 103, 897-904. [CrossRef] 
52. Jiménez-Galindo, J.C.; Malvar, R.A.; Butrón, A.; Santiago, R.; Samayoa, L.F.; Caicedo, M.; Ordás, B. Mapping of resistance to corn borers in a magic population of maize. BMC Plant Biol. 2019, 19, 431. [CrossRef]

53. Yi, Q.; Malvar, R.A.; Álvarez-Iglesias, L.; Ordás, B.; Revilla, P. Dissecting the genetics of cold tolerance in a multiparental maize population. Theor. Appl. Genet. 2019, 133, 503-516. [CrossRef]

54. López-Malvar, A.; Butron, A.; Malvar, R.A.; McQueen-Mason, S.J.; Faas, L.; Gómez, L.D.; Revilla, P.; Figueroa-Garrido, D.J.; Santiago, R. Association mapping for maize stover yield and saccharification efficiency using a multiparent advanced generation intercross (MAGIC) population. Sci. Rep. 2021, 11, 3425. [CrossRef]

55. Lopez-Malvar, A.; Malvar, R.A.; Butron, A.; Revilla, P.; Pereira-Crespo, S.; Santiago, R. Genetic dissection for maize forage digestibility traits in a multi-parent advanced generation intercross (MAGIC) population. Agronomy 2021, 11, 104. [CrossRef]

56. Grzesiak, M.T.; Waligorski, P.; Janowiak, F.; Marcińska, I.; Hura, K.; Szczyrek, P.; Głąb, T. The relations between drought susceptibility index based on grain yield (DSIGY) and key physiological seedling traits in maize and triticale genotypes. Acta Physiol. Plant. 2012, 35, 549-565. [CrossRef]

57. Iqbal, K.; Azhar, F.; Khan, E.I. Variability for drought tolerance in cotton (Gossypium hirsutum) and its genetic basis. Int. J. Agric. Biol. 2011, 13, 61-66.

58. Akinwale, R.O.; Awosanmi, F.E.; Ogunniyi, O.O.; Fadoju, A.O. Determinants of drought tolerance at seedling stage in early and extra-early maize hybrids. Maydica 2017, 62, 9.

59. Cao, L.; Wj, B. Discuss on evaluating method to drought-resistance of maize in seedling stage. J. Maize Sci. 2004, $12,73-75$.

60. Lynch, J.P.; Ho, M.D.; Phosphorus, L. Rhizoeconomics: Carbon costs of phosphorus acquisition. Plant Soil 2005, 269, 45-56. [CrossRef]

61. Shao, H.-B.; Chu, L.-Y.; Jaleel, C.A.; Zhao, C.-X. Water-deficit stress-induced anatomical changes in higher plants. Comptes Rendus Biol. 2008, 331, 215-225. [CrossRef]

62. Radic, V.; Vujakovic, M.; Marjanovic-Jeromela, A. Influence of drought on seedling development in different corn genotypes (Zea mays L.). J. Agric. Sci. Belgrade 2007, 52, 131-136. [CrossRef]

63. Aslam, M.; Maqbool, M.A.; Cengiz, R. Drought Stress in Maize (Zea mays L.). In Springer Briefs Agriculture; Springer: Berlin/Heidelberg, Germany, 2015.

64. Trampe, B.T.; Trampe, B.T. Assessment of Inducibility and Spontaneous Haploid Genome Doubling in Maize (Zea mays L.). Ph.D. Thesis, Iowa State University, Ames, IA, USA, 2019.

65. Giuliani, S.; Sanguineti, M.C.; Tuberosa, R.; Bellotti, M.; Salvi, S.; Landi, P. Root-ABA1, a major constitutive QTL, affects maize root architecture and leaf ABA concentration at different water regimes. J. Exp. Bot. 2005, 56, 3061-3070. [CrossRef]

66. Landi, P.; Sanguineti, M.; Liu, C.; Li, Y.; Wang, T.; Giuliani, S.; Bellotti, M.; Salvi, S.; Tuberosa, R. Root-ABA1 QTL affects root lodging, grain yield, and other agronomic traits in maize grown under well-watered and water-stressed conditions. J. Exp. Bot. 2006, 58, 319-326. [CrossRef]

67. Chai, W.; Peng, X.; Liu, B.; Wang, J.; Zhu, Z.; Liu, Y.; Zhao, K.; Cheng, B.; Si, W.; Jiang, H. Comparative genomics, whole-genome re-sequencing and expression profile analysis of nucleobase: Cation symporter 2 (NCS2) genes in maize. Front. Plant Sci. 2018, 9 , 856. [CrossRef]

68. Zhang, Q.; Liu, H.; Wu, X.; Wang, W. Identification of drought tolerant mechanisms in a drought-tolerant maize mutant based on physiological, biochemical and transcriptomic analyses. BMC Plant Biol. 2020, 20, 315. [CrossRef]

69. Wang, H.-Q.; Liu, P.; Zhang, J.-W.; Zhao, B.; Ren, B.-Z. Endogenous hormones inhibit differentiation of young ears in maize (Zea mays L.) under heat stress. Front. Plant Sci. 2020, 11, 533046. [CrossRef]

70. Li, Y.; Wang, X.; Li, Y.; Zhang, Y.; Gou, Z.; Qi, X.; Zhang, J. Transcriptomic analysis revealed the common and divergent responses of maize seedling leaves to cold and heat stresses. Genes 2020, 11, 881. [CrossRef]

71. Wang, Y.; Xu, J.; Ge, M.; Ning, L.; Hu, M.; Zhao, H. High-resolution profile of transcriptomes reveals a role of alternative splicing for modulating response to nitrogen in maize. BMC Genom. 2020, 21, 353. [CrossRef] [PubMed]

72. Li, H.; Yang, X.; Lu, M.; Chen, J.; Shi, T. Gene expression and evolution of Family-1 UDP-glycosyltransferases-insights from an aquatic flowering plant (sacred lotus). Aquat. Bot. 2020, 166, 103270. [CrossRef]

73. Castilhos, G.; Lazzarotto, F.; Spagnolo-Fonini, L.; Bodanese-Zanettini, M.H.; Margis-Pinheiro, M. Possible roles of basic helixloop-helix transcription factors in adaptation to drought. Plant Sci. 2014, 223, 1-7. [CrossRef] [PubMed]

74. Yamamoto, K.; Sakamoto, H.; Momonoki, Y.S. Maize acetylcholinesterase is a positive regulator of heat tolerance in plants. J. Plant Physiol. 2011, 168, 1987-1992. [CrossRef] [PubMed]

75. Choe, S.; Dilkes, B.; Gregory, B.D.; Ross, A.S.; Yuan, H.; Noguchi, T.; Fujioka, S.; Takatsuto, S.; Tanaka, A.; Yoshida, S.; et al. The arabidopsis dwarf1 mutant is defective in the conversion of 24-methylenecholesterol to campesterol in brassinosteroid biosynthesis. Plant Physiol. 1999, 119, 897-908. [CrossRef]

76. Chen, Z.; Liu, Y.; Yin, Y.; Liu, Q.; Li, N.; Li, X.; He, W.; Hao, D.; Liu, X.; Guo, C. Expression of AtGA2ox1 enhances drought tolerance in maize. Plant Growth Regul. 2019, 89, 203-215. [CrossRef]

77. Ogden, A.J.; Abdali, S.; Engbrecht, K.M.; Zhou, M.; Handakumbura, P.P. Distinct preflowering drought tolerance strategies of Sorghum bicolor genotype RTx430 revealed by subcellular protein profiling. Int. J. Mol. Sci. 2020, 21, 9706. [CrossRef]

78. Hu, J.; Ren, B.; Dong, S.; Liu, P.; Zhao, B.; Zhang, J. Comparative proteomic analysis reveals that exogenous 6-benzyladenine (6-BA) improves the defense system activity of waterlogged summer maize. BMC Plant Biol. 2020, 20, 44. [CrossRef] 
79. Castorina, G.; Domergue, F.; Chiara, M.; Zilio, M.; Persico, M.; Ricciardi, V.; Horner, D.S.; Consonni, G. Drought-responsive ZmFDL1/MYB94 regulates cuticle biosynthesis and cuticle-dependent leaf permeability. Plant Physiol. 2020, 184, $266-282$. [CrossRef]

80. Zenda, T.; Liu, S.; Wang, X.; Liu, G.; Jin, H.; Dong, A.; Yang, Y.; Duan, H. Key maize drought-responsive genes and pathways revealed by comparative transcriptome and physiological analyses of contrasting inbred lines. Int. J. Mol. Sci. 2019, 20, 1268 [CrossRef] [PubMed]

81. Zhang, X.; Lei, L.; Lai, J.; Zhao, H.; Song, W. Effects of drought stress and water recovery on physiological responses and gene expression in maize seedlings. BMC Plant Biol. 2018, 18, 68. [CrossRef]

82. Liu, S.; Zenda, T.; Jin, H.; Liu, G.; Wang, X.; Dong, A.; Yang, Y.; Duan, H. Global transcriptome and weighted gene co-expression network analyses of growth-stage-specific and hybrid-cultivar-specific drought stress responses in Maize. Res. Sq. 2020. [CrossRef]

83. Jagtap, A.B.; Vikal, Y.; Johal, G.S. Genome-Wide Development and Validation of Cost-E ff ective KASP Marker Assays for Genetic Dissection of Heat Stress Tolerance in Maize. Int. J. Mol. Sci. 2020, 21, 7386. [CrossRef]

84. Dong, A.; Yang, Y.; Liu, S.; Zenda, T.; Liu, X.; Wang, Y.; Li, J.; Duan, H. Comparative proteomics analysis of two maize hybrids revealed drought-stress tolerance mechanisms. Biotechnol. Biotechnol. Equip. 2020, 34, 763-780. [CrossRef]

85. Vendramin, S.; Huang, J.; Crisp, P.A.; Madzima, T.F.; McGinnis, K.M. Epigenetic regulation of ABA-induced transcriptional responses in maize. G3 Genes Genomes Genet. 2020,10, 1727-1743. [CrossRef]

86. Zhang, H.; Li, G.; Fu, C.; Duan, S.; Hu, D.; Guo, X. Genome-wide identification, transcriptome analysis and alternative splicing events of Hsf family genes in maize. Sci. Rep. 2020, 10, 8073. [CrossRef] [PubMed]

87. Zheng, X.; Li, Q.; Li, C.; An, D.; Xiao, Q.; Wang, W.; Wu, Y. Intra-kernel reallocation of proteins in maize depends on VP1-mediated scutellum development and nutrient assimilation. Plant Cell 2019, 31, 2613-2635. [CrossRef]

88. Rogers, E.D.; Benfey, P.N. Regulation of plant root system architecture: Implications for crop advancement. Curr. Opin. Biotechnol. 2015, 32, 93-98. [CrossRef]

89. Zhu, J.; Zhou, Y.; Li, J.; Li, H. Genome-wide investigation of the phospholipase c gene family in Zea mays. Front. Genet. 2021, 11, 1638. [CrossRef]

90. Hagemeyer, C. Transcriptome Analysis of Flood-Induced Hypoxia in Maize (Zea mays) Seedling Shoots; Florida State University: Tallahassee, FL, USA, 2018.

91. Yu, F.; Tan, Z.; Fang, T.; Tang, K.; Liang, K.; Qiu, F. A Comprehensive transcriptomics analysis reveals long non-coding RNA to be involved in the key metabolic pathway in response to waterlogging stress in maize. Genes 2020, 11, 267. [CrossRef] [PubMed]

92. Holland, J.B. Estimating genotypic correlations and their standard errors using multivariate restricted maximum likelihood estimation with SAS proc mixed. Crop Sci. 2006, 46, 642-654. [CrossRef]

93. Bradbury, P.J.; Zhang, Z.; Kroon, D.E.; Casstevens, T.M.; Ramdoss, Y.; Buckler, E.S. TASSEL: Software for association mapping of complex traits in diverse samples. Bioinformatics 2007, 23, 2633-2635. [CrossRef]

94. Endelman, J.B.; Jannink, J.-L. Shrinkage estimation of the realized relationship matrix. G3 Genes Genomes Genet. 2012, 2, 1405-1413. [CrossRef]

95. Li, J.; Ji, L. Adjusting multiple testing in multilocus analyses using the eigenvalues of a correlation matrix. Heredity 2005, 95, 221-227. [CrossRef]

96. Wang, N.; Akey, J.M.; Zhang, K.; Chakraborty, R.; Jin, L. Distribution of recombination crossovers and the origin of haplotype blocks: The interplay of population history, recombination, and mutation. Am. J. Hum. Genet. 2002, 71, 1227-1234. [CrossRef] [PubMed]

97. Barrett, J.C.; Fry, B.; Maller, J.; Daly, M.J. Haploview: Analysis and visualization of LD and haplotype maps. Bioinformatics 2004, 21, 263-265. [CrossRef] [PubMed]

98. Andorf, C.M.; Cannon, E.K.; Portwood, J.L.; Gardiner, J.M.; Harper, L.C.; Schaeffer, M.L.; Braun, B.L.; Campbell, D.A.; Vinnakota, A.G.; Sribalusu, V.V.; et al. MaizeGDB update: New tools, data and interface for the maize model organism database. Nucleic Acids Res. 2015, 44, D1195-D1201. [CrossRef] [PubMed] 